\title{
Defying the System: The Forgotten Rebellion of Abbaa Xoonee in Wallagga
}

\author{
Tesema Ta’a*
}

\begin{abstract}
The 1950s and the 1960s were crucial periods for the general African situation because it marked the advent of decolonization and eventual independence of the majority of the colonized peoples of the continent. At this time the pressure of independence and selfdetermination attained by other African countries and peoples has also been felt among the subjugated nations and nationalities in the empire-state of Ethiopia. In the 1950s and 1960s, several peasant rebellions took place in Ethiopia against the feudal regime of Emperor Hayla Sellase. Some of the major reasons of these turbulent rebellions in addition to conquest and subjugation of the last quarter of the nineteenth century included the imperial land and taxation policies as well as administrative injustice perpetrated against the peasant populations of the core regions and the peripheries. It was in the decades that followed the expulsion of the Italians from Ethiopia and the return of Emperor Hayla Sellase to power in 1941 that some of the rebellions such as the First Wayane Rebellion, the Gojjame Peasant Uprising and the Bale Peasant Revolt had occurred. All these discontents were suppressed by force of arms in which many lives were lost. It is significant to note that these rebellions have been more or less extensively dealt with by many Ethiopianist scholars. Moreover, the 1960 coup attempt led by the two brothers, Mengistu and Germame Neway has also been treated properly by the same writers. But unfortunately, the armed rebellion of most of the Nilo-Saharan peripheral peoples in western Wallagga which took place in 1945 E.C (1952/53 G.C) has been forgotten. This paper attempts to highlight the causes and the consequences of the Abbaa Xoonee rebellion. It will explain who Abba Xoonee was and what had happened to him when the rebellion was put down. It will also pay tribute to Abba Xoonee for he challenged the feudal oppression and exploitation exercised by Hayla Sellase's regime on his people without any social and economic benefits in return. The paper is largely based on oral sources, such as folklore and poems supplemented by some written accounts and circumstantial evidence.
\end{abstract}

\section{Introduction}

In the 1950s and1960s, several peasant rebellions took place in Ethiopia against the feudal regime of Emperor Hayla Sellase. There were several causes for the mounting grievances and rebellions. To mention but a few were the imperial policies, rampant corruption,

\footnotetext{
* Associate Professor, Department of History, Addis Ababa University
} 
human rights violations, lack of good governance as well as administrative injustices perpetrated against the peasant populations in many parts of the country in general and the marginalized ethnic groups in particular. The period was also crucial for the general African situation because it was at that time that decolonization and the eventual independence of the majority of the colonized peoples of the continent were attained.1

It was in the decades that followed the return of Emperor Hayla Sellase to power in 1941 that some rebellions such as the First Woyane Rebellion (1943), the Bale Peasant Rebellion (1963) and the Gojjame Peasant uprising (1968) had occurred.2 All of these violent actions were triggered either by some underlying and immediate causes such as ethnic oppression and taxation laws. The response of the feudal government was unequivocal. It suppressed all the uprisings by force of arms in which many lives were lost. It is significant to note that the rebellions were more or less extensively dealt with by many Ethiopianist scholars. Moreover, the 1960 coup attempt led by the two brothers, Mengistu and Garmame Neway 3 has also been treated properly by the same writers. But the challenges put up by the Maccaa Tuulamaa Association of the Oromo against Hayla Sellase's regime in the early 1960s, has largely been ignored or neglected deliberately by the so- called core Ethiopianist scholars. As Olaanaa Zogaa has pointed out in his recent book, the Maccaa Tuulamaa Association should have attracted the attention of genuine scholars as it was a movement for a just cause.4 But unfortunately most have been less interested or deliberately ignored the movement in support of the status quo and suppress the Oromo.

In the same vein the rebellions staged by most peripheral peoples of the Nilo-Saharan in western Wallagga have been rarely recorded. One of these rebellions was that of Abbaa Xoonee which took place in 1945 E.C (1952-53 G.C).

This paper attempts to highlight the causes and the consequences of the rebellion. It will explain who Abbaa Xoonee was and what happened to him when the rebellion was put down. It will also pay tribute to Abbaa Xoonee for he challenged the feudal oppression and exploitation exercised by Hayla Sellase's regime on his people without social and economic benefits in return. The paper is largely based on oral sources being supplemented by some written accounts and circumstantial evidence.

\section{Abbaa Xoonee: A Brief Biographical Survey}

The original common nomenclature of the Nilo-Saharan speakers in western Wallagga and western Gojjam was Gumuz. They were, however, divided into several clans and sub-clans with their own distinct names. Particularly those who live in western Wallagga have recently been included into one of the Regional States in Ethiopia known as the Benishangul Gumuz Regional State. Some of the Gumuz major clans and sub-clans who were historically very closely associated with the Oromo of Wallagga were: Darroo, Dabatsaa, Demoseega, Degubaa, Dendaa, Degufaa, Gabaxoo, Gomboo, Hagaloo and Kutalaa.5

It is very difficult if not impossible to know the exact birth date of a person among the non- literate societies because of lack of written records. Oral informants could only tell the year around which a certain person was born, usually in association with dramatic 
historical events such as Menilek's conquest of the South (1870s), the Battle of Embabo (1882), fought between the Gojjame and the Shawans and the Italian invasion of (1935/36). Accordingly, our informants agree that Abbaa Xoonee was born in the late 1880s when Ras Gobanaa was sent by Emperor Menilek to subdue western Wallagga.6

Abbaa Xoonee belonged to the Darroo clan one of the major groups of the NiloSaharan speaking Gumuz peoples in western Wallagga.7 The family of Abba Xoonee lived in Najjo district at a particular place called Tulluu Lubbu with Gaba Roobii (Wednsday market) village as its center. The area was relatively fertile with rich soil and the farmers produced cotton, coffee, maize, sorghum and varieties of other food crops. Most of the Gumuz including the Abbaa Xoonee's Darroo clan and family mainly lived on cultivation and hunting game for meat during their leisure time. They also kept cattle, goats and sheep. 8

The Darroo and other Gumuz clans, used to dispose their farm products to the weekly market in Najjo town which they attended in large numbers. Moreover, they had smaller markets like Gabaa Roobii near their villages where they exchanged their products with those of the surrounding Oromo. Several merchants from Najjo and Biilaa towns also went to the Darroo village markets where they could buy grain, cattle, sheep and goats at cheaper prices than what they could obtain from Najjo, Biilaa and Gimbii markets. 9

Our informants indicate that in the production of agricultural crops and trade transactions the Abbaa Xoonee clan and family used to play a prominent role. They also relate that the Abbaa Xoonee family had close relations with some Oromo families in Najjo, Biilaa and Gimbii towns. Abbaa Xoonee was liked, trusted and respected by almost all his clan members and the surrounding Oromo as well. Consequently, he was elected by a council of elders as an Abbaa Qoroo (head /chief of a sub- district) of the Darroo and other Gumuz clans of the area.10 Some one who had been elected as an Abbaa Qoroo in those days performed important duties of the government. He was made responsible for collection of taxes, maintenance of law and order as well as mobilization of his people for public works in time of peace and for war in cases of conflicts. The administrative structure of the region was systematically arranged by Emperor Hayla Sellassie's feudal governors of the time. Accordingly, the most important liaison officers who passed orders to the Gumuz were the Oromo chiefs who had the Gumuz Abbaa Qoroos under them responsible for running the day to day local administration and were accountable to the Oromo chiefs.11

As an Abbaa Qoroo, Abbaa Xoonee used to carry out his responsibilities. He was accountable to Qumbii Qanno, an Oromo chief administrator of the Darroo. But informants tell us that the peasants in his sub-district often complained to him that the poll tax required of them by the government was becoming burdensome and unbearable from year to year which in fact made Abbaa Xoonee himself very angry.12 For quite some time, he reported the complaints of the peasants against heavy taxation to his immediate chief Qumbii and the government authorities in Najjo and Gimbii but they were not in a position to solve the problem. Rather, the officials instructed Abbaa Xoonee to pass strict orders to his people to pay taxes on time and in case they refuse he was told to use the available police force in Najjo and Gimbii with an arrest warrant of those who did not pay taxes. They were all supposed to be thrown into jail.13 The behavior and action of the government authorities 
annoyed and disappointed Abbaa Xoonee and he at once took sides with his people who were discontented with the system of government and administration of Emperor Hayla Sellassie in general and the poll tax practices in particular.

According to my Gumuz informants who were close relatives of Abbaa Xoonnee, it was not only the burden of heavy taxation and mal-administration of the feudal regime of Emperor Hayla Sellassie that sparked off the Rebellion of Abbaa Xoonee but more serious was the raping of the wives and daughters and at times the kidnapping of Gumuz boys and girls by the tax collectors which triggered the conflict.14 For example, as the immediate cause of the initial clash a man named Dheereesaa Kokolfaa, an Oromo who had an affair with the wife of a Gumuz man named Yambuu was killed by the latter at a place called Saaye Mi'oftuu within the territory of Abbaa Xoonee Qoroo.15

Consequently, the wife of Dheereesaa was very sad and angry at the death of her husband. She promptly went to Gimbii to appeal the case of an illegal assassination of her husband to Ato Mekonnen Desta, the then governor of the area. Ato Mekonnen accepted her application and sent a number of police men with a letter to Abbaa Xoonee the Abbaa Qoroo of the place ordering him to help the policemen to capture the criminal. When the policemen arrived, Abbaa Xoonee was not at home. He had gone to Limmu to the northeast of his village on a business trip. Moreover, most of the Gumuz males were also not in the village of Tulluu Lubuu near Gabaa Roobii and the policemen only found women, young girls and children in and around the village.16

The policemen asked the women and children where Abbaa Xoonee and other males were. They were told that Abbaa Xoonee was in Limmu and the rest of the males went for hunting game. Then the policemen entered the local drinking houses and began drinking local beer and araqi (locally made alcoholic drink). Soon they got intoxicated and began to flirt with the Gumuz women and girls and even raped some of them by force. Then the other women communicated the case to the males who went for hunting in the nearby Saaye forest. The Gumuz men immediately returned to their villages and an open clash broke out between the policemen and the Gumuz.17

As a result some government policemen and a few Gumuz men became victims of the first clash. Even Gudinaa Koluu and Gomoroo Qumbii, the two Gumuz strong men who allegedly were accused of killing Dheeresaa Kokolfa and were imprisoned earlier had escaped from where they were detained and joined the fighting force of the Gumuz against the policemen.

This tragic news had reached Abbaa Xoonee who was on his way back to his village riding his mule named Mollaa and he had arrived on the very day the serious clash took place. Before Abbaa Xoonee dismounted from his mule the policemen who were quite vexed at what had happened at Abbaa Xoonee's village shot his mule, Mollaa which died on the spot.18

Informants clearly indicate that the action of the policemen had further infuriated Abbaa Xoonee. Consequently, he was said to have exchanged some statements with his brother, Dorsaa as follows:

Abaa Xoonee: "My brother Dorsaa what has happened in my village? Is the country not peaceful and tranquil?" 
Dorsaa: "My dear brother, Abbaa Xoonee! There is no peace at all! The village is almost destroyed by the government policemen."

Abbaa Xoonee: "You are right! Peace has already been broken down by government authorities and the policemen who had massacred our people who have not committed any crime and they also killed my mule, Mollaa. We have been oppressed too much. Now it is beyond our tolerance." He went on to say: If fire is set on one's own house, one has to try to do his best to extinguish the fire even if it requires one's own cloth."19

Then Abbaa Xoonee told his brother, Dorsaa to get him his rifle with enough ammunition. He also passed orders to all Gumuz able bodied men to get ready for any eventualities of a final show down with the enemy forces. Meanwhile, the government policemen who had survived the clash went back to Gimbii and reported the whole incident to Ato Mekonnen Desta, the governor, under whose order they had undertaken the operation. Following the initial incident, Abbaa Xoonee soon called a meeting of the top council of elders from various villages under him to discuss what had actually happened in his village and to plan what course of action the Darroo and the other Gumuz peasants should take.20

\section{Eruption of the Rebellion}

The meeting of the Gumuz and more particularly that of the Darroo council of elders which was held under the leadership of Abbaa Xoonee undertook a long discussion concerning the actions of the policemen in his village, the poll tax collections, the behavior of government officials and their mal-administration. In particular the council had considered the recent clash between the policemen and the Gumuz at the Darroo village as a very serious offence on the part of the government. The participants of the meeting reached a consensus that the general system of governance was so bad that they were not in a position to accept any orders from government authorities, be it poll tax payment or otherwise. They also agreed to take up arms against any one who tried to enforce government orders in their villages. But before they took action they decided to send Abbaa Xoonee to Gimbii to gather some intelligence information on Fitawrari (later Dajjazmach) Yemane Gebre Egziabher, the then awrajja governor of Gimbii. ${ }^{21}$ Abbaa Xoonee was instructed by the Darroo council of elders to check the amount of firearms the awrajja governor possessed and the number of guards and soldiers he might mobilize against the Gumuz.

Our informants clearly remember that Abbaa Xoonee went to the office of Fitawrari Yemane disguising himself as an ordinary peasant who wanted to submit an application to the governor. When he entered the office, he found Fitawrari Yemane on his chair. He greeted him and submitted his application. To his surprise Abbaa Xoonee saw only one old rifle at a corner behind the governor and two body guards. He immediately began to compare the amount of firearms in the possession of his people and that of the governor. He at once naively concluded that the awraja governor's firearms and the number of his guards was no match to the overwhelming number of arms and his people respectively. ${ }^{23}$

Abbaa Xoonee went back to his village and gave a detailed information on his findings to the council of elders who sent him to Gimbii. The council members and Abbaa Xoonee 
himself soon began to disseminate rumors and made a massive propaganda campaign in every Gumuz village not to pay poll taxes and to shoot at any one who attempted to collect taxes for the government. ${ }^{24}$ Indeed, Abbaa Xoonee became a ring leader of this venture. Within a short time more or less the whole Gumuz clan and sub-clans were mobilized for an armed uprising against the local government officials and authorities. Although the Gumuz were for long disappointed at the government appointees and some of the highland traders and police men who usually raped their daughters and wives, their grievances were initially directed against the poll tax collectors and their supporters.

In the middle of 1944 E.C. Fitawrari Yemane gave orders to Qanyazmach Tafaraa Tuchoo, Captain Shiifaraaw Yaadataa and Qanyazmach Mekonnen Eshete to collect land use taxes from the Gumuz whose Abbaa Qoroo was Abbaa Xoonee. Nevertheless, Abbaa Xoonee and his people not only refused to pay taxes but also moved to a strategic area of Ennemay Boshe in Bojjii Dirmmajjii and hid themselves in the dense forest of Kamashi. Moreover, killings of traders and some passers-by in Darroo, the sub-district of Abbaa Xoonee Qoroo were reported. The situation soon grew into an open rebellion against the government leading to a general breakdown of law and order in the Gumuz villages, particularly in places like Gabaa Roobii and Tulluu Lubuu where the first clash had occurred. Consequently, in the year 1945, the awraja governor was said to have mobilized a large scale expeditionary force which came to be known as Duula Abbaa Xoonee which literally means 'The Expedition of Abbaa Xoonee'. The incident is still remembered among the local people bearing the name of the great man of Darroo district. ${ }^{25}$

\section{Duula Abbaa Xoonee (The Campaigns of Abbaa Xoonee)}

According to Emiru Gebre, one of our informants who at the time was a deputy governor of Najjo district, about sixty-eight armed men most of them Oromo were mobilized under the leadership of Qanyazmach Fayisaa Dheeraa and were sent to force the Gumuz to pay taxes. But the Gumuz under their tactful leader, Abbaa Xoonee were already informed about the forces that were sent against them by the governor of Gimbii. They had several firearms and enough ammunition and were ready to confront their enemies. In fact, Etafa Biyanaa indicated that by the time the government forces headed towards the domain of Abbaa Xoonee about two hundred well armed Gumuz were eating, drinking and firing shots in the air making a sort of war game. He also further related that the Gumuz never attack others unless they were provoked. ${ }^{26}$

Among the government contingents Grazmach Yaadataa Rorrisaa was a long time tax collector in the region and knew almost all the villages in the area. Qanyazmach Fayisaa Dheeraa, the head of the government forces was an experienced fighter who had the tendency of undermining enemy forces. In addition to the sixty-eight armed men there were also some peasant militia who were recruited from all districts of Gimbii awraja as well as some from Naqamtee, Arjoo and Horroo Gudruu awrajas to join the campaign.

The Gumuz who were organized under Abbaa Xoonee were the first to refuse the payment of taxes which was soon followed by others. In the event of the initial combat between the government's expeditionary forces and those of Abbaa Xoonee the latter had obtained an upper hand over the former. According to Emiru Gebre, government forces lost 
some of their important figures including Qanyazmach Fayisaa Dheeraa, Mekonnen Eshete and Balambaras Gaanfuree. On the Gumuz side only a few of Abbaa Xoonee's fighters had died. But Abbaa Xoonee managed to escape and continued to reorganize his followers for further struggle. Nevertheless, the government forces were soon reinforced with more weapons and man power. Even some contingents of the Imperial Body Guards were sent from Addis Ababa to support the provincial soldiers particularly making an effective use of artillery. The Gumuz were terrified, gave up a conventional warfare and resorted to guerrilla tactics with their intrepid leader, Abbaa Xoonee. But many of Abbaa Xoonee's followers complained that what he had reported to them earlier concerning the weapons possessed by government forces was not the reality. They then commented about the armament of the government soldiers as follows:

$\begin{array}{cc}\text { Oromo } & \text { Gloss } \\ \text { Xiyyitin jara kanaa } & \begin{array}{c}\text { The bullets of these people (body } \\ \text { Guards) }\end{array} \\ \text { Muka jala naanayee nama rukuta. }{ }^{27} & \begin{array}{c}\text { Can strike persons around and/ or } \\ \text { under a tree. }\end{array}\end{array}$

Fitawrari Yemane, the governor of Gimbii was very angry against the outcome of the first encounter between his troops and the Gumuz in which some of the prominent notables lost their lives. He reported the magnitude of the clash between the government troops and the Gumuz to Dajjazmach Dereje Mekonnen, the then governor of Wallagaa province. In his report he asked for more weapons of war and more soldiers in order to eliminate the criminals or capture them and bring them to justice. The provincial governor took a prompt action by sending more troops with enough firearms to Gimbii. In the mean time, the Gumuz moved into the junction of the Abbay and the Dhidheessa river valleys where they hid themselves taking advantage of the inaccessible natural fortress of the landscape. ${ }^{28}$

The newly mobilized, reinforced and organized government troops were given orders by the governor to hunt down the Gumuz outlaws. During this second campaign some of the Gumuz were captured. When they were asked to identify those who killed the prominent people in the first campaign they replied with a total denial. They in fact said every body was firing and no one knew who killed those who were dead. When the troops were informed that some Gumuz villagers made war-cries and put butter on their heads which is the sign of a hero, they at once marched on to the Gumuz villages. They captured women, children and the elderly whereas the stronger ones escaped and took to the bush. The armed men of the government were bitter and they burnt down the Gumuz villages and corn fields as well as robbed their cattle. ${ }^{29}$ Within less than half a day the government troops managed to put the majority of the Gumuz under their total control but still some of the strong ones escaped to far off places. Consequently, they set the dense forest on fire and painted their rifles with charcoal to make it similar with their own color so that the enemy forces may not locate them easily. It is said that this tactic helped many Gumuz warriors to survive.

Abba Xoonee was among those who had managed to escape during the second campaign as well. According to Dajjazmach Yemane the expedition was named after 
Abbaa Xoonee who became famous because his close followers were the ones who seriously challenged the Oromo chiefs and the commanders of the government soldiers. Yemane further indicated that another immediate cause of the major conflict in addition to the initial clash with the policemen at the Gumuz village near Gabaa Roobii was that a certain Oromo was given money from his Gumuz friend to buy him a gun. But the Oromo neither bought him a gun nor returned the money to his Gumuz friend. The Gumuz man became furious that he in collaboration with his friend killed the Oromo and escaped. According to the Gumuz tradition they do not hand over their member to the government authorities even if they knew he has committed a crime. Beginning with this incident and the earlier ones a feeling of hostility and disagreement existed between the Gumuz under Abbaa Xoonee and the Oromo of the area. ${ }^{30}$

Following the second clash in which the Gumuz were completely defeated, Abbaa Xoonee was captured by the government soldiers and was brought to Gimbii. Dajjazmach Yemane, the awraja governor consulted Dajjazmach Dereje Mekonnen, the provincial governor on how to handle Abbaa Xoonee, the chief rebel now under arrest. At the time many people thought that Abbaa Xoonee may be given a capital punishment by the government of Hayla Sellassie. Surprisingly enough, however, Dajjazmach Dereje passed orders to Dajjazmach Yemane that Abba Xoonee be given amnesty but should designate a notable person from Gimbii as a guarantor before he was set free. Ato Desta Chekol, a well known merchant of Gimbii who was a close friend of Abbaa Xoonee was willing to become his guarantor and Abbaa Xoonee was set free in spite of the criminal charges against him. $^{31}$

Although Abbaa Xoonee was given amnesty, the Oromo whose friends and relatives lost their lives as well as those peasant militia who were forced to fight against the rebels were not happy. It is, therefore, said that the surrounding Oromo expressed dissatisfaction in the following folklore:

Oromo

Abbaa Xoonee nama(garba) gadhee gadaanii

Yokaan loltee hinjabaanee

Yokaan baddee hinfaganee

Ilma namaa tamsaaftee

Ganna gadhee kanaanii. ${ }^{32}$

\section{Gloss}

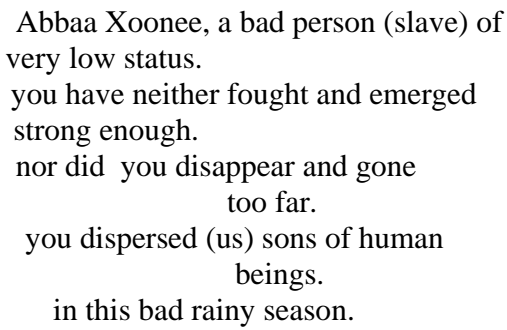

The folklore clearly reveals that the Oromo in the area seem to have favored the success of Abbaa Xoonee's rebellion but it did not happen. That is why they reflected their anxiety and frustration in such a way as if the failures were due to the faults of Abbaa Xoonee.

The expedition of Abbaa Xoonee was headed by prominent Oromo commanders and militia men. Consequently, the Gumuz considered the Oromo chiefs as their main enemies. 
According to traditions related to us by our informants, however, there were no hostility between the Oromo and the Gumuz in the earlier centuries. In fact informants confirmed that the different groups of the Nilo-Saharan peoples including the Gabaxoo, Mao, Goma and others in the Dhiidheesaa, Angar, Daabbus and Saaye river valleys were made to settle by the Oromo Abbaa Qoroos and prominent personalities. The Oromo and the Nilo Saharans had created smooth symbiotic and reciprocal relations of peaceful co-existence since the early times of their encounter. In the nineteenth and early twentieth centuries for instance, the Oromo employed some Nilo Saharans as workers on cotton fields, wild honey collectors, beehive honey producers, cattle tenders and other similar activities. ${ }^{33}$

The objective of the Gumuz rebellion led by Abbaa Xoonee which was basically against the government's taxation system did not materialize. The uprising was put down in the two campaigns organized by the government authorities. But it had negative implications and had created unnecessary hostilities between the Gumuz and the Oromo of the surrounding area who in fact should have collaborated with one another against the oppressive regime which, I think, could have quickened the collapse of Hayla Sellassie's government.

Even though the Abbaa Xoonee rebellion was crushed within about six months by the government soldiers and the militia forces and was short-lived; the intention and the inherent desire was not only to resist but also to take a concrete action against the oppressors which became exemplary for others being reflected in the living memories left behind as the legacy of the Gumuz rebellion. As George Washington had once commented concerning the American War of Independence, the Gumuz took up arms for a just cause that is in defense of freedom which is their birth right. The suppression of the feudal regime and the heavy handedness of the administrative structures became more and more acute with the passage of time. The contradictions between the rulers and the ruled in the whole country in general and the suffering of the local peasantry almost everywhere in particular had continued unabated. In this connection it is significant to note that the genre of causes that triggered the rebellion of Abbaa Xoonee in Wallagga in the early 1950s had ultimately led to the outbreak of the Ethiopian Revolution of 1974.

Finally, although written sources are scarce or even non-existent to deal with historical events such as those of the rebellion of Abbaa Xoonee, particularly among the peoples of the periphery in Ethiopia as well as in other African countries, scholars have to make tireless efforts in studying significant events among the marginalized societies to redress the existing historiographical imbalance. It is if and only if this is recognized and genuine action is taken that the peoples of the peripheries begin to have a sense of belongingness to Ethiopia.

\section{Notes}

1. John Iliffe, Africans: The History of A Continent (Cambridge University

Press, 1995, 1996 \& 2000), pp.243-262.

2. For detailed treatment of the peasant rebellions in Ethiopia see, Gebru Tareke, Ethiopia: Power and Protest, Peasant Revolts in the Twentieth Century (Cambridge: 1991).

3. Bahru Zewde, A History of Modern Ethiopia 1855-1974 (London: James Currey 
1991), pp. 211-215.

4. Olaanaa Zogaa, Gizitna Gizot: Yemaccaa Tuulamaa Meredaja Mahiber (Metcha Tulema's Association), Addis Ababa: Bole Printing Press, 1985 E.C. The book has 565 pages of a detailed and well interpreted historical account of the Maccaa Tuulamaa Association in Amharic.

5 Interview: Teessoo Labataa, Ayaanaa Teessoo, Sanbataa Fereji, Sept. 2007.

6 Interview: Qanyazmach Abdisaa Mosaa, Naqamtee, Grazmach Ettafaa Biyanaa. Gimbii, 1979.

7. Tesema Ta'a, “The Oromo of Wollega: A Historical Survey to 1910," M.A.Thesis, A.A.U. History Department, 1980. See also Alessandro Triulzi, Salt, Gold and Legitimacy: Prelude to the History of a No-Man's Land, Bela Shangul, Wallagga, Ethiopia (ca. 1800-1898), 1981.

8. Tesema Ta'a, “The Political Economy of Western Central Ethiopia: From the Mid-16 to the Early $20^{\text {th }}$ Centuries,” PhD. Dissertation, M.S.U., 1986.

9. Interview: Ato Kitilaa Challaa, Najjo, 1980.

10. Interview: Graz. Ettafaa Biyanaa, Ato Nagarii Jammo, Gimbii, 1979.

11. Interview: Teessoo Labataa, Ayanaa Teessoo, Kamashi Zone, Sept. 2007.

12. Interview: Graz. Ettafaa Biyanaa, Ato Nagarii Jammo, Gimbii, 1979.

13. Interview: Ato Emiru Gabre, Qany, Abdisaa Mosaa, Naqamtee, 1979.

14. Interview: Teessoo Labata, Kamashi Zone, Sept. 2007.

15. Interview: Sanbata Fereji, Kamashi Zone, Sept. 2007.

16. Interview: Ayanaa Teessoo, Kamashi Zone, Sept. 2007.

17. Interview: Teessoo Labataa, Kamashi Zone, Sept. 2007.

18. Ibid.

19. Interviw: Ayanaa Teessoo, Teessoo Labataa, Sanbataa Fereji, Kamashi Zone, Sept. 2007.

20. Dajjazmach Yemane Gabre Egziabher, Naqamtee, 2002. This informant was the Aw raja governor of Gimbii during the time of Abbaa Xonee's Rebellion. I am greatly indebted to Ato Alemu Shuie, my former M.A. student and advisee who interviewed Dajjazmach Yemane, Ato Emiru Gabre and many others in Naqamtee in 2001 and 2002, on the subject upon my request.

21. Interview Ato Nuru Bokoore, Ato Emiru Gabre, Naqamtee, 2002.

22. Ibid.

23. Interview: Dajjazmach Yemane Gabre Egziabher, Ato Emiru Gabre, Naqamtee, 2002.

24. Ibid.

25. Interview: Ato Regassa Gutta, Ato Berhaanu Nagarii, Naqamtee, 2002.

26. Interview: Ato Emiru Gabre, Naqamtee, 2002.

27.Ibid

28. Interview: Dajjazmach Yemane Gabre Egziabher, Naqamtee, 2002.

29. Interview: Ato Nuru Bokoore, Ato Emiru Gabre, Naqamtee, 2002.

30. Interview: Graz. Ettafaa Biyanaa, Ato Nagarii Jammo, Gimbii, 1979.

31. Interview: Dajjazmach Yemane Gabre Egziabher, Naqamtee, 2002.

32. Interview: Ato Abarraa Bariiyoo, Finfinnee, 2003. He very well remembers the 
folklore in the form of songs which expressed the rebellion of Abbaa Xonee. He told me that it was quite popular among the elders of Najjo during his childhood.

33. Interview: Qanyazmach Abdiisaa Mosaa, Grazmach Tamiru Gutaa, Naqamtee, 1980.

\section{References}

Atieb Ahmed Dafala. "Sheikh Kojale Al-Hassen and Bela Shangul 1825-1938," B.A. thesis, History Department, Addis Ababa University, 1973.

Bahru Zewde. “Dejazmach Jote Tulu, 1855-1918,” B.A. thesis, History Department, Addis Ababa University, 1970.

. A History of Modern Ethiopia 1855-1974. London: James Currey, 1991.

Bender, M.L. The Ethiopian Nilo- Saharan. Addis Ababa: 1975.

Cerulli, Enrico. Etiopia Occidentale. Dallo socioa alla frontiera del Sudan.II. Roma: Sindacata italiana arti grafiche, 1933.

The Peoples of southwest Ethiopia and Its Borderland. London: International Institute, 1956.

Gabriel, S.C. Pagan Tribes of the Nilotic Sudan. London: 1933.

Gebru Tareke. Ethiopia: Power and Protest, Peasant Revolts in the Twentieth Century. Cambridge: 1991.

Gemechu Taye, "The History of Macha-Tulama Association, AAU, BA Thesis Department of History, 1993.

Grottanelli, C.G. Missione ethnografica nel Uollega occidentale. I Mao. Roma: Academia d' Italia, 1940.

Iliffe, John. The History of A Continent. Cambridge University Press, 1995, 1996\& 2000.

James, W.R. "Social Assimilation and Changing Identity in Southern Funj," Sudan in Africa, 1968.

Olaanaa Zogaa. Gizitna Gizot: Yemacca Tuulamaa Meredaja Mahiber. Addis Ababa: Bole Printing Press, 1985 E.C.

Tesema Ta'a. "The Oromo of Wollega: A Historical Survey to 1910," M.A. thesis, History Department, Addis Ababa University, 1980.

. "The Political Economy of Western Central Ethiopia: from the Mid-16 ${ }^{\text {th }}$ Century to the Early $20^{\text {th }}$ Centuries,” Ph.D. dissertation, M.S.U. 1986. "A Brief Historical Account of the Goma of the Ethio-Sudanese Frontier (ca. 1880s-1950)," in Lan , Gender and the Periphery: Themes in the

History of Eastern and Southern Africa, Bahru Zewde(eds.), Addis

Ababa: OSSREA, 2003.

. The Political Economy of an African Society in Transformation: Case of Maccaa Oromo (Ethiopia), Wiesbaden: Otto Harrasstowitz. GmbH \& Co. KG, 2006.

Triulzi, A. Salt, Gold and Legitimacy: A Prelude to the History of a No-Man's Land, Bela Shangul, Wallagga, Ethiopia (ca. 1800-1898), 1981.

Yasin Mohammed. "The Komo of Gidami,” B.A. thesis, History Dept, Addis Addis Ababa University, 1982.

"Historical Study of the Land Tenure System in Highland Illubabor C.1889-

1974,” MA Thesis, School of Graduate Studies, Dept of History, AAU, 1990. 